\title{
The Histological Analysis of the Glenohumeral "Critical Zone"
}

\author{
Análisis Histológico de la "Zona Crítica" Glenohumeral
}

\author{
N. Naidoo*; L. Lazarus* \& K. S. Satyapal*
}

NAIDOO, N.; LAZARUS, L. \& SATYAPAL, K. S. The histological analysis of the glenohumeral "critical zone". Int. J. Morphol., 34(3):1051-1057, 2016.

SUMMARY: The arterial integrity of the "critical zone" of the rotator cuff has led to much uncertainty regarding rotator cuff tendinopathy. As the region of the supraspinatus tendon is the most common area affected by impingement, its central aspect is situated approximately $10 \mathrm{~mm}$ from the insertion at the greater humeral tubercle. Although many studies have investigated the vascularity of the "critical zone", there still appears to be lack of consensus regarding its extent. Through the employment of gross dissection and standard histology analysis of twenty-five adult bilateral cadaveric scapulo-humeral regions $(n=50)$, this study aimed to quantify the degree of vascularity, or lack thereof, within the "critical zone" by evaluating its relative morphometric features. The demographic representation of the sample was also considered. Results: i) Mean diameter of arteriole lumen: 91.6 $\pm 75.2 \mu \mathrm{m}$; ii) Mean diameter of entire arteriole: 119.8 $\pm 87.1 \mu \mathrm{m}$; iii) Mean arteriole wall thickness: $15.1 \pm 9.5 \mu \mathrm{m}$; iv) Mean area occupied by an arteriole: $20644.4 \pm 3358.0 \mu \mathrm{m}^{2}$; v) Mean number of arterioles within "critical zone": 14.6 \pm 8.7. All tissue samples displayed a scarce distribution of arterioles along the musculotendinous junction relative to the "critical zone". A directly proportional relationship between the morphometric parameters was indicated by positive strong correlations and accompanying statistically significant $\mathrm{P}$ values. As $66 \%$ of the number of arterioles within the "critical zone" were distributed between the minimum value and the upper quartile, it was postulated to be hypovascular, therefore confirming the findings of previous studies.

KEY WORDS: “Critical zone”; Arterioles; Vascularity; Morphometric parameters.

\section{INTRODUCTION}

As a well-defined functional-anatomic unit, the rotator cuff is primarily a dynamic stabilizer of the glenohumeral joint generating active movement (Morag $e t$ al., 2006). It appears as a musculotendinous confluence of four muscles, viz, subscapularis, supraspinatus, infraspinatus and teres minor (Standring et al., 2008; Muscolino, 2010). Although the anterior subscapularis originates from the subscapular fossa to insert onto the lesser humeral tubercle, the remaining posterior muscles arise from the supraspinous and infraspinous fossae, respectively, and attach onto the greater humeral tubercle (Sinnatamby, 2006; Standring et al.; Muscolino).

The "critical zone", initially recognized by Codman, is situated within the deeper layers of the central aspect of the supraspinatus tendon, approximately $10 \mathrm{~mm}$ from the distal insertion to the proximal humerus (Codman, 1931; Rockwood et al., 2004; Kovacevic \& Rodeo, 2008; Seitz et al., 2011). It is most closely related to the articular region of the supraspinatus tendon and is represented by the anastomosis between the osseous and muscular arterioles (Rathburn \& Macnab, 1970; Chansky \& Iannotti, 1991).

Despite Kolliker's (1850) presumption that tendons were devoid of an arterial supply, this notion was later revised by Schäfer (1912) who successfully provided a concise description of the blood vessels related to muscles and tendons. On the contrary, the extent of the arterial distribution within the rotator cuffs "critical zone", or the complete absence of it, has created much debate (Seitz et al.).

Although there are varying reports in the literature regarding the degree of vascularity of the "critical zone", it is generally considered to be characterized by decreased vascularity and is commonly referred to as the "watershed" region (Seitz et al.) (Table I). Subsequently, authors have described it as being hypovascular (Codman; Macnab, 1973; Lohr \& Uhthoff, 1990; Brooks et al., 1992; Determe et al.,

\footnotetext{
* Department of Clinical Anatomy School of Laboratory Medicine and Medical Sciences College of Health Sciences University of KwaZulu-Natal Westville Campus Private Bag X54001, Durban, South Africa, 4000.
} 
1996; Kane et al., 2006; Adler et al., 2008; Levy et al., 2008), avascular (Rathburn \& Macnab; Herberts et al., 1981; Ling et al., 1990; Chansky \& Iannotti) or hypervascular (Seitz et al.) (Table I).

Barr (2004) postulated avascularity to arise from the compression and attrition of the supraspinatus tendon in a narrowed subacromial space. Since Ling et al., identified the central aspect of the "critical zone" to display a distinct curve corresponding to the superior-most aspect of the humeral head, the position of the arm may account for the arterial integrity. Moreover, Chung \& Steinbach (2010) identified the "critical zone" as the region of the supraspinatus tendon most commonly affected by impingement. However, whether the vascular nature of the "critical zone" acts as a direct stimulant of rotator cuff degeneration, or whether it indicates the ensuing pathological state of the rotator cuff, such patho-anatomic entities remain unknown (Seitz et al.).

Therefore, the purpose of this study was to quantify the degree of vascularity, or lack thereof, within the "critical zone" by investigating its relative morphometric features.

\section{MATERIAL AND METHOD}

Following the bilateral macroscopic dissection of twenty-five adult cadaveric scapulo-humeral regions $(\mathrm{n}=$ 50 ), each tissue specimen was then subjected to general histological procedure. The standard hematoxylin and eosin (H\&E) stained sections were digitally scanned through the use of the Leica Microsystems Software 2.0. The morphometric features pertaining to the "critical zone" were then obtained through the SlidePath Gateway Client Viewer 2.0. A total of three microscopic field areas per slide were studied.

The demographic representation of the sample was as follows:

$$
\begin{aligned}
& \text { Sex: } \text { Female }=10 ; \text { Male }=15 \\
& \text { Race: } \text { Black }=5 ; \text { White }=20 \\
& \text { Age: Mean }=70.9 \pm 16.7 \text { years old; } \\
& \text { Range }=37-97 \text { years' old }
\end{aligned}
$$

The minimum, maximum and mean morphometric parameters that were recorded included the diameters of the arteriole lumen and entire arteriole, thickness of the arteriole wall, the area occupied by an arteriole and the number of arterioles within the "critical zone" (Fig. 1: A-D).

The possible correlation between side, sex, race and age and the morphometric parameters was assessed using SPSS version 21.0 (SPSS Inc., Chicago, Illinois, USA). A P value of $<0.05$ was considered to be statistically significant. The distribution of the number of arterioles within the "critical zone" was evaluated by the Skewness and Kurtosis Tests. In addition, the degree of vascularity was determined by ranking the number of arterioles in the "critical zone" within and around the boundaries of three quartile points as well as the computed minimum and maximum values.

As per the University of KwaZulu-Natal's protocol

\begin{tabular}{|c|c|c|c|c|}
\hline \multirow[t]{2}{*}{ Author (Year) } & \multirow[t]{2}{*}{ Sample No. } & \multicolumn{3}{|c|}{ Arteriole Distribution } \\
\hline & & Hypovascular & Avascular & Hypervascular \\
\hline Codman (1934) & 100 & $\checkmark$ & & \\
\hline Rathburn \& Macnab (1970) & Not recorded & & $\checkmark$ & \\
\hline Macnab (1973) & Not recorded & $\checkmark$ & & \\
\hline Herberts et al. (1981) & 131 & & $\checkmark$ & \\
\hline Ling et al. (1990) & 42 & & $\checkmark$ & \\
\hline Lohr \& Uhthoff (1990) & 18 & $\checkmark$ & & \\
\hline Chansky \& Iannotti (1991) & Not recorded & & $\checkmark$ & \\
\hline Brooks et al. (1992) & 16 & $\checkmark$ & & \\
\hline Determe et al. (1996) & 25 & $\checkmark$ & & \\
\hline Kane et al. (2006) & 72 & $\checkmark$ & & \\
\hline Adler et al. (2008) & 31 & $\checkmark$ & & \\
\hline Levy et al. (2008) & Not recorded & $\checkmark$ & & \\
\hline Seitz et al. (2011) & Not recorded & & & $\checkmark$ \\
\hline
\end{tabular}
of ethical conduct, ethical approval was granted (Ethical Clearance Approval Number: BE280/13).

Table I. Literature summarizing the arteriole distribution of the "critical zone" 


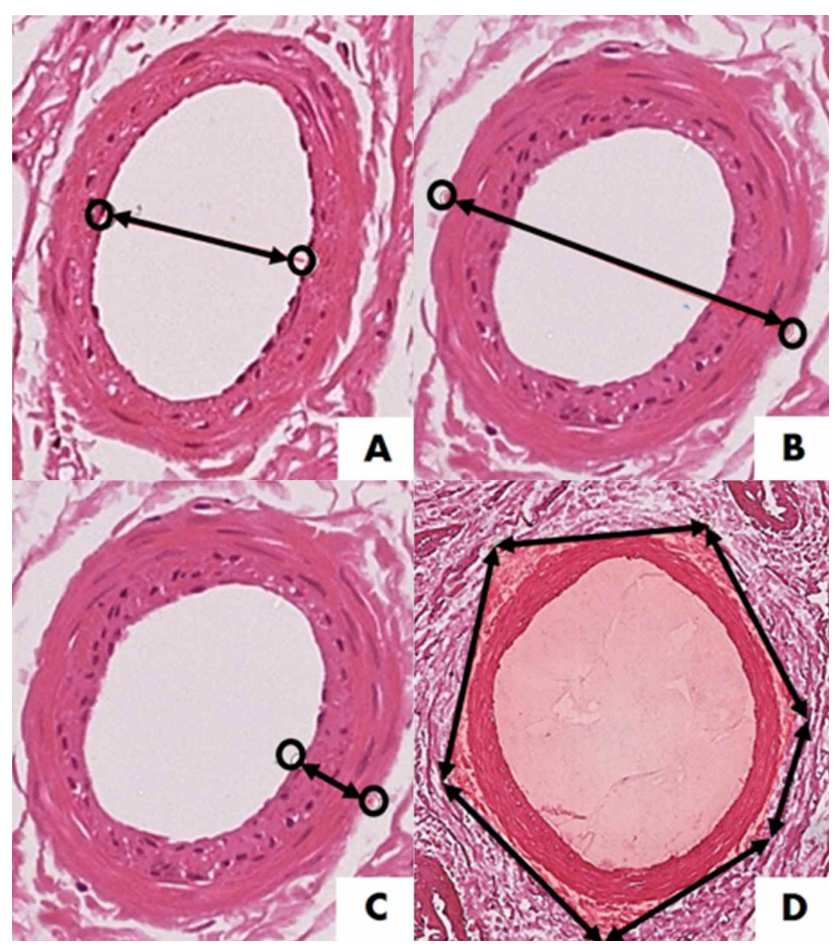

Fig. 1. Morphometric parameters relating to the arteriole distribution of the "critical zone" - A: Diameter of arteriole lumen $(13$ x $200 \mu \mathrm{m})$; B: Diameter of entire arteriole (13 x $200 \mu \mathrm{m})$; C: Thickness of arteriole wall $(27 \times 100 \mu \mathrm{m})$; D: Area occupied by an arteriole $(7 \mathrm{x} 500 \mu \mathrm{m})$.

\section{RESULTS}

In all tissue samples, evidence of vascularity was only seen along the musculo-tendinous junction relative to the "critical zone" (Fig. 2).
The morphometric parameters were analyzed as both standard and demographic-specific data.

The diameter of the arteriole lumen varied from a minimum of $10.1 \mathrm{~mm}$ to a maximum of $379.7 \mu \mathrm{m}$ with a standard mean value of $91.6 \pm 75.2 \mu \mathrm{m}$ (Table II). The mean diameters of the arteriole lumen on the left and right sides were $86.7 \pm 73.8 \mu \mathrm{m}$ and $96.56 \pm 77.66 \mu \mathrm{m}$, respectively (Table II). Male individuals presented with arteriole lumen diameters of $89.7 \pm 67.5 \mu \mathrm{m}$ while female individuals had mean arteriole lumen diameters of $94.5 \pm 87.2 \mu \mathrm{m}$ (Table II). With regard to race, the mean diameter of the arteriole lumen in White individuals was $91.4 \pm 91.9 \mu \mathrm{m}$, whereas in Black individuals it appeared as $92.7 \pm 41.2 \mu \mathrm{m}$ (Table II).

Although the standard mean diameter of an entire arteriole appeared to be $119.8 \pm 87.1 \mu \mathrm{m}$, corresponding minimum and maximum diameters of $16.0 \mathrm{~mm}$ and 463.9 $\mu \mathrm{m}$ were recorded (Table II). The mean diameter of an entire arteriole on the left side was $111.3 \pm 82.0 \mu \mathrm{m}$ while that of the right side was $128.4 \pm 92.7 \mu \mathrm{m}$ (Table II). Mean diameters of $121.6 \pm 81.8 \mu \mathrm{m}$ and $117.3 \pm 96.6 \mu \mathrm{m}$ of an entire arteriole was recorded for males and females, respectively (Table II). In White individuals the mean diameter of an entire arteriole was found to be $118.4 \pm 94.7 \mu \mathrm{m}$, whereas Black individuals displayed a mean diameter of $125.5 \pm 48.5 \mu \mathrm{m}$ (Table II).

The arteriole wall demonstrated a standard mean thickness of 15.1 $\pm 9.5 \mu \mathrm{m}$ (Minimum: $1.9 \mu \mathrm{m}$; Maximum: $40.4 \mu \mathrm{m})$ (Table II). On the left and right sides, the mean arteriole wall thickness was $13.6 \pm 8.6 \mu \mathrm{m}$ and $16.5 \pm 10.3 \mu \mathrm{m}$, respectively (Table II). The mean thickness of the arteriole wall in male individuals was seen to be $16.3 \pm 9.6 \mu \mathrm{m}$ and 13.2 $\pm 9.3 \mu \mathrm{m}$ in female individuals. White and Black

Table II. Morphometric Parameters relating to the arteriole distribution of the "critical zone".

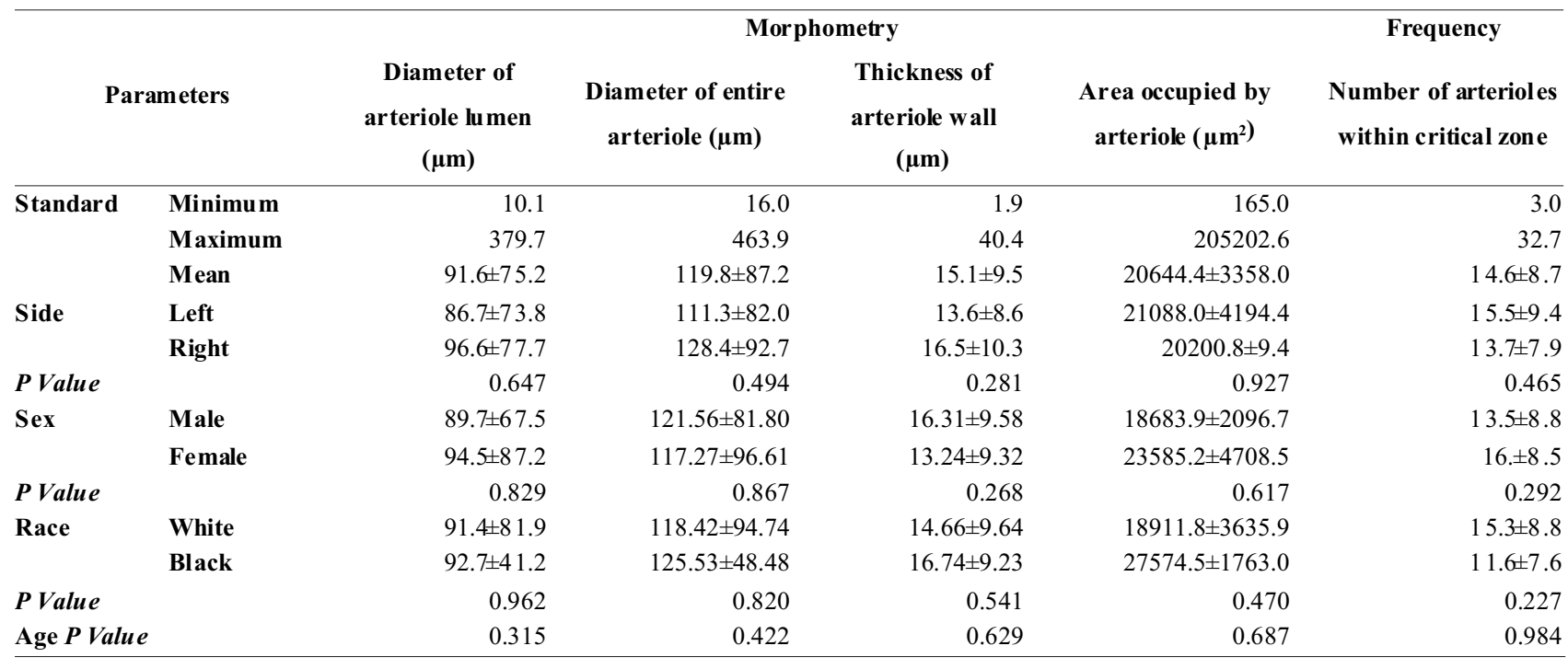




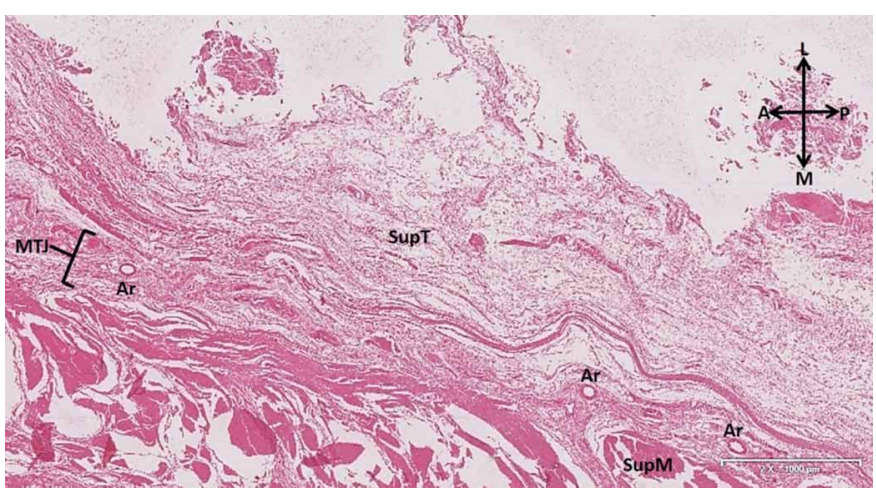

Fig. 2. Supero-lateral view of the arteriole distribution at the musculotendinous junction relative to the "critical zone" $(2$ x $1000 \mu \mathrm{m})$. A. Anterior; Ar. Arteriole; L. Lateral; M. Medial; MTJ; Muscle-tendinous junction; P. Posterior; SupM; Supraspinatus muscle; SupT. Supraspinatus tendon.

individuals presented with corresponding mean arteriole wall

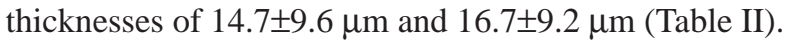

The standard mean area occupied by an arteriole was measured to be 20644.4 $\pm 3358.0 \mu \mathrm{m}^{2}$ (Minimum: $165.0 \mu \mathrm{m}^{2}$; Maximum: $205202.6 \mu \mathrm{m}^{2}$ ) (Table II). The mean area occupied by an arteriole on the left side was found to be $21088.0 \pm 4194.4$ $\mu \mathrm{m}^{2}$, while that of the right side was $20200.8 \pm 9.4 \mu \mathrm{m}^{2}$ (Table II). Male and female individuals demonstrated mean arteriole areas of $18683.9 \pm 2096.7 \mu \mathrm{m}^{2}$ and $23585.2 \pm 4708.5 \mu \mathrm{m}^{2}$, respectively (Table II). In White and Black individuals relative mean arteriole areas of $18911.8 \pm 3635.9 \mu \mathrm{m}^{2}$ and $27574.5 \pm 1763.0 \mu \mathrm{m}^{2}$ were recorded (Table II).

The standard number of arterioles within the "critical zone" ranged from a minimum of 3.0 to a maximum of 32.7 , with a mean frequency of $14.6 \pm 8.7$ (Table II). The mean number of arterioles on the left and right sides appeared to be 15.5 \pm 9.4 and $13.7 \pm 7.9$, respectively (Table II). Although male individuals presented with a mean of $13.5 \pm 8.8$ arterioles, female individuals had a mean of $16.2 \pm 8.5$ arterioles (Table II). In White and Black individuals, the mean number of arterioles was noted to be $15.3 \pm 8.8$ and 11.6 \pm 7.7 , correspondingly (Table II). In addition, the analysis of the distribution of the number of arterioles within the "critical zone" yielded values of 0.472 and 0.834 for the Skewness and Kurtosis Tests, respectively (Fig. 3).

Upon correlation of the morphometric parameters with one another, the following Pearson Product Moment Correlation Coefficients ( $\mathrm{r}$ ) and accompanying $\mathrm{P}$ values were recorded (Table III):

i) Diameter of arteriole lumen vs. Diameter of entire arteriole: $\mathrm{r}=0.982 ; \mathrm{P}=0.000$

ii) Diameter of arteriole lumen vs. Thickness of arteriole wall: $r=0.660 ; P=0.000$

iii) Diameter of arteriole lumen vs. Area occupied by an arteriole: $\mathrm{r}=0.861 ; \mathrm{P}=0.000$

iv) Diameter of arteriole lumen vs. Number of arterioles within the "critical zone": $r=0.150 ; P=0.297$

v) Diameter of entire arteriole vs. Thickness of arteriole wall: $\mathrm{r}=0.775 ; \mathrm{P}=0.000$

vi) Diameter of entire arteriole vs. Area occupied by an arteriole: $\mathrm{r}=0.840 ; \mathrm{P}=0.000$

vii) Diameter of entire arteriole vs. Number of arterioles within the "critical zone": $r=0.128 ; P=0.000$

viii) Thickness of arteriole wall vs. Area occupied by an arteriole: $\mathrm{r}=0.590 ; \mathrm{P}=0.000$

xi) Thickness of arteriole wall vs. Number of arterioles within the "critical zone": $r=0.098 ; \mathrm{P}=0.498$

$\mathrm{x})$ Area occupied by an arteriole vs. Number of arterioles within the "critical zone": $r=0.169 ; \mathrm{P}=0.241$

Table III. Correlation of the morphometric parameters regarding the arteriole distribution of the "critical zone"

\begin{tabular}{|c|c|c|c|c|c|}
\hline Parameters & $\begin{array}{l}\text { Diameter of } \\
\text { arteriole lumen }\end{array}$ & $\begin{array}{l}\text { Diameter of entire } \\
\text { arteriole }\end{array}$ & $\begin{array}{l}\text { Thickness of } \\
\text { arteriole wall }\end{array}$ & $\begin{array}{l}\text { Area occupied by } \\
\text { arteriole }\end{array}$ & $\begin{array}{l}\text { Number of } \\
\text { arterioles } \\
\text { within critical } \\
\text { zone }\end{array}$ \\
\hline \multirow[t]{2}{*}{ Diameter of arteriole lumen } & & $r=0.982^{\#}$ & $r=0.660^{\#}$ & $r=0.861^{\#}$ & $r=0.150 \ldots$ \\
\hline & & $P$ Value $=0.000^{*}$ & $P$ Value $=0.000^{*}$ & $P$ Value $=0.000^{*}$ & $P$ Value $=0.297$ \\
\hline \multirow{2}{*}{ Diameter of en tire art eriole } & $r=0.982^{\#}$ & & $r=0.775^{\#}$ & $r=0.840^{\#}$ & $r=0.128 \#$ \\
\hline & $P$ Value $=0.000^{*}$ & & $P$ Value $=0.000^{*}$ & $P$ Value $=0.000^{*}$ & $P$ Value $=0.375$ \\
\hline \multirow[t]{2}{*}{ Thickness of arteriole wall } & $r=0.660^{\#}$ & $r=0.775_{\#}$ & & $r=0.590^{\#}$ & $r=0.098 \ldots$ \\
\hline & $P$ Value $=0.000^{*}$ & $P$ Value $=0.000^{*}$ & & $P$ Value $=0.000^{*}$ & $P$ Value $=0.498$ \\
\hline \multirow[t]{2}{*}{ Area occupied by arteriole } & $r=0.861^{\#}$ & $r=0.840^{\#}$ & $r=0.590^{\#}$ & & $r=0.169 \ldots$ \\
\hline & $P$ Value $=0.000^{*}$ & $P$ Value $=0.000^{*}$ & $P$ Value $=0.000^{*}$ & & $P$ Value $=0.241$ \\
\hline \multirow{2}{*}{$\begin{array}{l}\text { Number of arterioles within } \\
\text { critical zone }\end{array}$} & $r=0.150^{\# \#}$ & $r=0.128 \ldots$ & $r=0.098^{\#}$ & $r=0.169^{\#}$ & \\
\hline & $P$ Value $=0.297$ & $P$ Value $=0.375$ & $P$ Value $=0.498$ & $P$ Value $=0.241$ & \\
\hline
\end{tabular}

* Significant P Value \# Positive strong correlation \#\# Positive week correlation. 


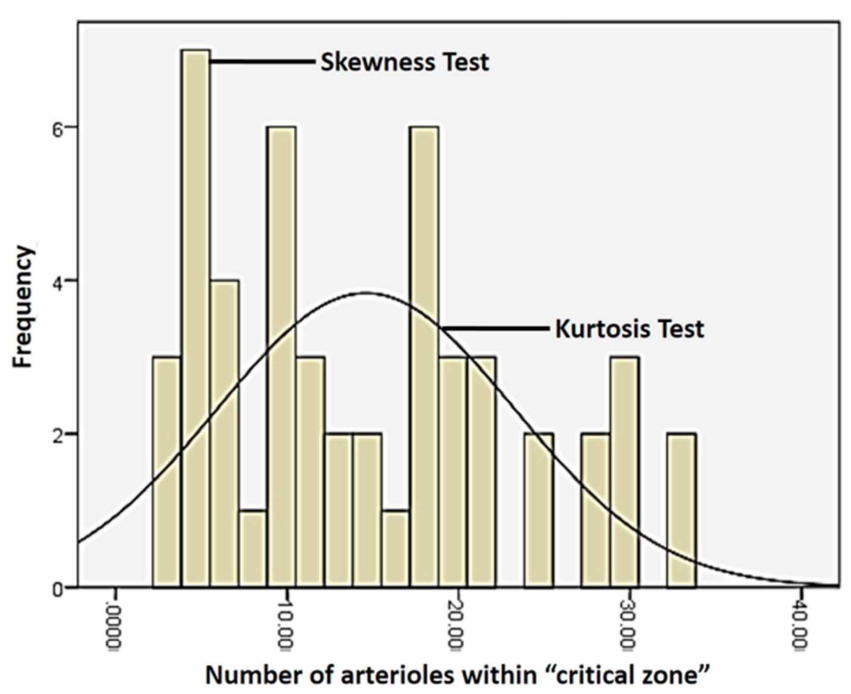

Fig. 3. Histogram displaying the distribution of the number of arterioles within the "critical zone"

\section{DISCUSSION}

Sharma \& Maffulli (2006) documented that the arterial supply to all tendinous regions generally arises from three distinct sources - viz. Intrinsic system situated at the musculo-tendinous junction, intrinsic system located at the osteo-tendinous junction and the extrinsic system via the paratenon or synovial sheath. As the principal arterial source of the supraspinatus muscle-tendon complex, the suprascapular artery ramifies within the muscular belly to convey an anastomotic network across the musculotendinous junction to supply the distal portions of the supraspinatus tendon (Moseley \& Goldie, 1963; Ling et al.; Determe et al.; Standring et al.; Naidoo et al., 2014).

In the current study, all tissue samples displayed a scarce distribution of arterioles along the musculo-tendinous junction only, relative to the "critical zone" of the supraspinatus muscle-tendon complex. According to Peacock (1959) and de Palma et al., (2011), the musculotendinous junction is considered to be a physiological tissue interface. Due to its situation between the muscular and tendinous aspects of the muscle in question, it portrays a weak susceptible nature which predisposes it to tension and subsequent injury (de Palma et al.). More recently, through laser Doppler analysis, Kathikeyan et al., (2015) demonstrated the variable arteriole distribution throughout the pathologic rotator cuff and found that the blood flow was highest at the musculo-tendinous junction as opposed to other regions of the tendon.
Despite the general focus on the degree of vascularity within the "critical zone", no previous study provided both standard and demographic-specific data regarding the morphometric parameters of the "critical zone". However, the range of the standard diameter of the entire arteriole $(16.0-463.9 \mu \mathrm{m})$ recorded in this study was significantly increased compared to the range of $10-100 \mu \mathrm{m}$ reported by Mescher (2013) (Table II). Contrary to the statement of Determe et al. that the quantification of arteriole diameters was impossible, the present study proceeded to do so.

Although the arteriole wall thickness and relative diameters of an entire arteriole and its lumen were larger on the right side, the area occupied by an arteriole and the number of arterioles within the "critical zone" were greater on the left side (Table II).

Female individuals appeared to present with larger diameters of the arteriole lumen and a greater area occupied by an arteriole. The diameter of an entire arteriole and the arteriole wall thickness were all increased in male individuals. Additionally, female "critical zones" manifested a higher number of arterioles than that of male individuals (Table II).

In light of the smaller representation of the Black race group within the sample, arteriole wall thickness, the area occupied by an arteriole and the diameters of the arteriole lumen and an entire arteriole were found to be increased in Black individuals (Table II). Conversely, the number of arterioles within the "critical zone" were marginally higher in White individuals (Table II).

Despite the association of the nature of the "critical zone" with the process of aging in previous studies, the present study did not reveal any effect of age on the morphometric parameters of the "critical zone" (Rathburn \& Macnab).

Although no significant $\mathrm{P}$ values were recorded for the comparison of the morphometric parameters with the respective demographic factors, the present study investigated demographic trends that were not previously reported.

The correlation of the morphometric parameters with one another gave rise to two different types of relationships (Table III):

a) Positive strong correlations were identified for the following comparisons:

i) Diameter of arteriole lumen vs. Diameter of entire arteriole $(\mathrm{r}=0.982)$

ii) Diameter of arteriole lumen vs. Thickness of arteriole wall $(r=0.660)$ 
iii) Diameter of arteriole lumen vs. Area occupied by an arteriole $(\mathrm{r}=0.861)$

iv) Diameter of entire arteriole vs. Thickness of arteriole wall $(\mathrm{r}=0.775)$

v) Diameter of entire arteriole vs. Area occupied by an arteriole $(r=0.840)$

vi) Thickness of arteriole wall vs. Area occupied by an arteriole $(r=0.590)$

In addition, all positive strong correlations were accompanied by statistically significant $\mathrm{P}$ values, thus indicating the directly proportional relationship between these parameters (Table III).

b) Positive weak correlations were identified for the following comparisons:

vii) Diameter of arteriole lumen vs. Number of arterioles within the "critical zone"

viii) Diameter of entire arteriole vs. Number of arterioles within the "critical zone"

xi) Thickness of arteriole wall vs. Number of arterioles within the "critical zone"

x) Area occupied by an arteriole vs. Number of arterioles within the "critical zone"

Interestingly, positive weak correlations were recorded for all relationships comparing the Number of arterioles within the "critical zone" with the remaining four morphometric parameters. Since these correlations indicated positive directions with weak strengths that were not accompanied by levels of significance, the distribution of the number of arterioles within the "critical zone" were further investigated by means of the Skewness and Kurtosis Tests (Fig. 3).

As a measure of asymmetry, the Skewness Test yielded a positive value of 0.472 which indicated that the data pertaining to the number of arterioles within the "critical zone" was skewed to the right and approximately symmetric (Fig. 3). Hence the distribution of the number of arterioles within the "critical zone appeared to be more stretched on the side above the mean (Fig. 3).

The negative Kurtosis value of -0.834 suggested that the central peak of the data was lower and broader compared to that of the normal, therefore the number of arterioles within the "critical zone" demonstrated a flat distribution (Fig. 3).

With regard to the degree of vascularity within the "critical zone", the number of arterioles within the "critical zone" were ranked within and around the boundaries of the minimum and maximum values and three quartile points, viz. minimum $=3.00 ;$ maximum $=32.67 ;$ lower $/ 1^{\text {st }}$ quartile $=6.00$; median $/ 2^{\text {nd }}$ quartile $=12.83 ;$ upper $/ 3^{\text {rd }}$ quartile $=20.00$.
The "critical zone" was thus postulated to be hypovascular as $66 \%$ of the number of arterioles within the "critical zone" were distributed between the minimum value and the upper $/ 3^{\text {rd }}$ quartile. This corroborated the findings of previous studies (Codman; Macnab; Lohr \& Uhthoff; Brooks et al.; Kane et al.; Adler et al.; Levy et al.).

\section{CONCLUSION}

This study investigated the morphometric parameters of the "critical zone" in accordance with demographic factors. The degree of vascularity within the "critical zone" was postulated to resemble hypovascularity. Since arteriole compression may ultimately regress to ischemia of the rotator cuff muscle complex, the healing process of the supraspinatus tendon is dependent upon the role of certain intrinsic (vascularity) and extrinsic (impingement by adjacent structures) factors. As there is no "gold" standard for the therapeutic management of rotator cuff tendinopathy, knowledge of the gross anatomy of the "critical zone" may help to elucidate its aetiological role in susceptibility and healing, thus restoring healthy tissue function.

NAIDOO, N.; LAZARUS, L. \& SATYAPAL, K. S. Análisis histológico de la "zona crítica" glenohumeral. Int. J. Morphol., 34(3):1051-1057, 2016.

RESUMEN: La integridad arterial de la "zona crítica" del manguito rotador ha dado lugar a una gran incertidumbre con respecto a la tendinitis del mismo. A medida que la región del tendón del músculo supraespinoso sea el área más común afectada por el impacto, su aspecto central estará situado aproximadamente a $10 \mathrm{~mm}$ desde la inserción en el tubérculo mayor del húmero. Aunque muchos estudios han investigado la vascularización de la "zona crítica", aún parece existir falta de consenso en cuanto a su extensión. A través de la disección macroscópica y análisis de la histología normal de ambas regiones escápulo-humerales, se realizó en 25 cadávers adultos $(n=50)$, este estudio que tuvo como objetivo cuantificar el grado de vascularización, o su ausencia, dentro de la "zona crítica" mediante la evaluación de su características morfométricas. También se consideró la representación demográfica de la muestra. Resultados: i) La media de diámetro de lumen de las arteriolas: $91,6 \pm 75.2 \mu \mathrm{m}$; ii) El diámetro medio de la totalidad de las arteriolas: $119,8 \pm 87.1 \mu \mathrm{m}$; iii) la media del espesor de la pared de las arteriolas: $15,1 \pm 9.5 \mu \mathrm{m}$; iv) La media de la zona ocupada por una arteriola: $20.644,4 \pm 3358.0 \mu \mathrm{m}^{2}$; v) La media de las arteriolas dentro de la "zona crítica": 14,6 $\pm 8,7$. Todas las muestras de tejidos tenían una escasa distribución de las arteriolas a lo largo de la unión músculo-tendinosa con relación a la "zona crítica". Una relación directamente proporcional entre los parámetros morfométricos indica fuertes correlaciones positivas y junto a valores de $\mathrm{P}$ estadísticamente significativos. Como el $66 \%$ de las arteriolas dentro de la "zona crítica" se distribuyeron entre el valor de cuartil mínimo y superior, se postuló como hipovascular, por lo tanto confirma los resultados de estudios anteriores.

PALABRAS CLAVE: Zona crítica; Arteriolas; Vascularidad; Parámetros morfométricos. 


\section{REFERENCES}

Adler, R. S.; Fealy, S.; Rudzki, J. R.; Kadrmas, W.; Verma, N. N.; Pearle, A.; Lyman, S. \& Warren, R. F. Rotator Cuff in Asymptomatic Volunteers: Contrast-enhanced US Depiction of Intratendinous and Peritendinous Vascularity Rotator cuff in asymptomatic volunteers: contrast-enhanced US depiction of intratendinous and peritendinous vascularity. Radiology, 248(3):954-61, 2008.

Barr, K. P. Rotator cuff disease. Phys. Med. Rehabil. Clin. N. Am., 15(2):47591, 2004.

Brooks, C. H.; Revell, W. J. \& Heatley, F. W. A quantitative histological study of the vascularity of the rotator cuff tendon. J. Bone. Joint Surg. Br., 74(1):151-3, 1992.

Chansky, H. A. \& Iannotti, J. P. The vascularity of the rotator cuff. Clin. Sports Med., 10(4):807-22, 1991.

Chung, C. B. \& Steinbach, L. S. MRI of the Upper Extremity: Shoulder, Elbow, Wrist and Hand. Philadelphia, Wolters Kluwer Health/Lippincott Williams \& Wilkins, 2010.

Codman, E. A. \& Akerson, I. B. The pathology associated with rupture of the supraspinatus tendon. Ann. Surg., 93(1):348-59, 1931.

de Palma, L.; Marinelli, M.; Pavan, M. \& Bertoni-Freddari, C. Involvement of the muscle-tendon junction in skeletal muscle atrophy: an ultrastructural study. Rom. J. Morphol. Embryol., 52(1):105-9, 2011.

Determe, D.; Rongières, M.; Kany, J.; Glasson, J. M.; Bellumore, Y.; Mansat, M. \& Becue, J. Anatomic study of the tendinous rotator cuff of the shoulder. Surg. Radiol. Anat., 18(3):195-200, 1996.

Herberts, P.; Kadefors, R.; Anderson, G. \& Petersén, I. Shoulder pain in industry: an epidemiological study on welders. Acta Orthop. Scand., 52(3):299-306, 1981.

Kane, S. M.; Dave, A.; Haque, A. \& Langston, K. The incidence of rotator cuff disease in smoking and non-smoking patients: a cadaveric study. Orthopedics, 29(4):363-6, 2006.

Karthikeyan, S.; Griffin, D. R.; Parsons, N.; Lawrence, T. M.; Modi, C. S.; Drew, S. J. \& Smith, C. D. Microvascular blood flow in normal and pathologic rotator cuffs. J. Shoulder Elbow Surg., 24(12):1954-60, 2015.

Kölliker, A. Mikroskopische Anatomie oder Gewebelehre des Menschen. Leipzig, Verlag von Wilhelm Engelmann, 1850.

Kovacevic, D. \& Rodeo, S. A. Biological augmentation of rotator cuff tendon repair. Clin. Orthop. Relat. Res., 466(3):622-33, 2008.

Levy, O.; Relwani, J.; Zaman, T.; Even, T.; Venkateswaran, B. \& Copeland, $\mathrm{S}$. Measurement of blood flow in the rotator cuff using laser Doppler flowmetry. J. Bone Joint Surg. Br., 90(7):893-8, 2008.

Ling, S. C.; Chen, C. F. \& Wan, R. X. A study on the vascular supply of the supraspinatus tendon. Surg. Radiol. Anat., 12(3):161-5, 1990.

Lohr, J. F. \& Uhthoff, H. K. The microvascular pattern of the supraspinatus tendon. Clin. Orthop. Relat. Res., (254):35-8, 1990.

Macnab, I. Rotator cuff tendinitis. Ann. R. Coll. Surg. Engl., 53(5):271-87, 1973.
Mescher, A. L. Junqueira's Basic Histology: Text and Atlas. 13th ed. New York, McGraw-Hill Medical, 2013.

Morag, Y.; Jacobson, J. A.; Miller, B.; De Maeseneer, M.; Girish, G. \& Jamadar, D. MR imaging of rotator cuff injury: what the clinician needs to know. Radiographics, 26(4):1045-65, 2006.

Moseley, H. F. \& Goldie, I. The arterial pattern of the rotator cuff of the shoulder. J. Bone Joint Surg. Br., 45(4):780-9, 1963.

Muscolino, J. E. The Muscular System Manual: The Skeletal Muscles of the Human Body. 3rd ed. St. Louis, Mosby/Elsevier, 2010.

Naidoo, N.; Lazarus, L.; De Gama, B. Z.; Ajayi, N. O. \& Satyapal, K. S. Arterial supply to the rotator cuff muscles. Int. J. Morphol., 31(1):13640, 2014.

Peacock, E. E. Jr. A study of the circulation in normal tendons and healing grafts. Ann. Surg., 149(3):415-28, 1959.

Rathburn, J. B. \& Macnab, I. The microvascular pattern of the rotator cuff. $J$. Bone Joint Surg. Br., 52(3):540-53, 1970.

Rockwood, C. A.; Matsen, F. A.; Wirth, M. A. \& Lippitt, S. B. The Shoulder. 3rd ed. Philadelphia, Saunders, 2004.

Schäfer, E. A. Text-Book of Microscopic Anatomy. 11th ed. London, Longmans \& Green, 1912.

Sinnatamby, C. S. Last's Anatomy: Regional \& Applied. 11th ed. Edinburgh, Churchill Livingstone, 2006.

Sharma, P. \& Maffulli, N. Biology of tendon injury: healing, modeling and remodeling. J. Musculoskelet. Neuronal Interact., 6(2):181-90, 2006.

Standring, S. Gray's Anatomy: The Anatomical Basis of Clinical Practice. 40th ed. Edinburgh, Elsevier, 2008.

Seitz, A. L.; McClure, P. W.; Finucane, S.; Boardman, N. D. 3rd. \& Michener, L. A. Mechanisms of rotator cuff tendinopathy: intrinsic, extrinsic, or both? Clin. Biomech. (Bristol, Avon), 26(1):1-12, 2011.

\section{Correspondence: \\ Professor K. S. Satyapal \\ Department of Clinical Anatomy \\ School of Laboratory Medicine and Medical Sciences \\ College of Health Sciences \\ University of KwaZulu-Natal \\ Private Bag X54001 \\ Durban \\ 4000 \\ SOUTH AFRICA}

Email address: satyapalk@ukzn.ac.za
Received: 23-02-2016

Accepted: $18-07-2016$ 